\title{
Impact of urban growth on surface climate: A case study in Oran, Algeria
}

\author{
Lahouari Bounoua \\ NASA's Goddard Space Flight Center, code 614.4, Greenbelt, MD, USA
}

Abdelmounaine Safia

Algerian Space Agency, Center for Space Techniques, Arzew, Algeria

Jeffrey Masek

NASA's Goddard Space Flight Center, code 614.4, Greenbelt, MD, USA

Christa Peters-Lidards

NASA's Goddard Space Flight Center, code 614.5, Greenbelt, MD, USA

Marc L. Imhoff

NASA's Goddard Space Flight Center, code 614.4, Greenbelt, MD, USA

May 02, 2008

Corresponding author address: Lahouari Bounoua, NASA's Goddard Space Flight

Center, code 614.4, Greenbelt, MD. E-mail: Lahouari.Bounoua@nasa.gov 


\section{ABSTRACT}

We develop a land use map discriminating urban surfaces from other cover types over a semiarid region in North Africa and use it in a land surface model to assess the impact of urbanized land on surface energy, water and carbon balances.

Unlike in temperate climates where urbanization creates a marked heat island effect, this effect is not strongly marked in semiarid regions. During summer, the urban class results in an additional warming of $1.45^{\circ} \mathrm{C}$ during daytime and $0.81^{\circ} \mathrm{C}$ at night compared to that simulated for needleleaf trees under similar climate conditions. Seasonal temperatures show urban areas warmer than their surrounding during summer and slightly cooler in winter. The hydrological cycle is practically "shut down" during summer and characterized by relatively large amount of runoff in winter.

We estimate the annual amount of carbon uptake to 1.94 million metric tons with only $11.9 \%$ assimilated during the rainy season. However, if urbanization expands to reach $50 \%$ of the total area excluding forests, the annual total carbon uptake will decline by $35 \%$ and the July mean temperature would increase only $0.10^{\circ} \mathrm{C}$, compared to current situation. In contrast, if urbanization expands to $50 \%$ of the total land excluding forests and croplands but all short vegetation is replaced by native broadleaf deciduous trees, the annual carbon uptake would increase $39 \%$ and the July mean temperature would decrease by $0.9{ }^{\circ} \mathrm{C}$, compared to current configuration. These results provide guidelines for urban planners and land use managers and indicate possibilities for mitigating the urban heat. 


\section{Introduction}

Cities are at the center of a rapidly changing socio-economic environment. During last decades, the world has experienced unprecedented urban expansion, especially in developing countries. In terms of ecological impact, urbanization is one of the most significant and long lasting forms of land use and cover change and its extent of increase is linked to population growth and economic development. The world population is expected to increase by 2.6 billion over the next 50 years from today's 6.5 billion. Remarkably however, a large part of this growth is expected to take place in developing regions of the world, where about 5.3 billion people live today. Population is expected to reach 7.8 billion by 2050 in developing nations but remain roughly unchanged at around 1.2 billion in the industrialized nations (POPIN 2007).

Urbanization affects surface climate by altering the carbon, water and energy budgets through several physical mechanisms, 1) the reduction in the fraction of vegetated area which reduces photosynthesis, and consequently reduces transpiration and interception loss 2) the modification of surface roughness and albedo and 3) the change in surface hydrology. These physical mechanisms are tightly coupled land-atmosphere processes and their alteration may have important impacts on local and regional climate. Urbanization appears to be a minor form of land transformation when viewed from the perspective of the amount of area it currently occupies. Current estimates show for example that urbanization in the US occupies about $3 \%$ of the total area; yet it reduced the net primary production by about $1.6 \%$; offsetting the $1.8 \%$ gain obtained from agricultural expansion (Imhoff et al. 2004). 
Cities are composed of large areas of pavement and buildings and less vegetation cover compared to surrounding areas. However, they are not all built the same way nor are they built with the same material. For example, in some U.S cities, the material used in buildings and pavement construction is dark and absorbs a significant amount of solar energy instead of reflecting it, causing the surfaces and the air around them to warm faster contributing to the so-called "urban heat island" effect (Grimmond et al. 2002; Shepherd and Burian 2003; Quattrochi and Ridd 1994; Quattrochi et al. 2007). In some arid and semi arid regions, however buildings are often light colored and thus more reflective. In these regions, urban areas exhibit a relatively weak urban heat island (UHI) and sometimes even an urban heat sink if the region is under extensive irrigation (Hafner and Kidder 1999, Shepherd 2006).

Urbanization exerts environmental, climatic and socio-economic pressures that are not yet fully comprehended. While some studies have assessed the impact of pollution, air and water quality in semi-arid regions (Boughedaoui and Kerbachi 2008; Kerbachi et al., 2007) and others have examined the interactions of ecosystems with land cover change (Goetz et al. 2004) a lot remains to be done to quantify the effect of urbanization on local surface climate through assessment of the carbon, water and energy exchanges at local space and time scales. It is generally agreed that understanding urban climate and its modeling is critically linked to spatial and temporal scales ranging from local to mesoscale (Grimmond et al., 2002). The city is thus considered in its entirety and is differentiated from its surroundings areas of forests and agriculture so that processes represent the integrated response of an ensemble of vegetation and paved surfaces. In this paper we document the impact of urbanization, as a form of land use, on the surface 
energy, water and carbon budgets from local to annual scales in a semi arid city along the Mediterranean cost of North Africa. We use high resolution Landsat data for 2002 to characterize the urban setting in Oran, a city in the North African country of Algeria whose population has grown more than $230 \%$ in the last fifty years (http://books.mongabay.com/population estimates/full/Oran-Algeria.html). While this growth has directly increased the demand for housing and industrial buildings, of more importance has been the impact on ecology and local climate. The city's economic growth during the last 50 years has led to extensive urbanization mostly at the expense of agricultural land and native vegetation. This region is of importance not only for its growth rate but most importantly because it is confined between the large Sahara desert and the Mediterranean Sea and represents a typical semi arid region vulnerable to complete desertification.

\section{Data and Model}

\section{a. Study area}

The city of Oran, located on the Mediterranean coast of Algeria (figure 1), has undergone extensive economic development over the last 50 years which triggered a significant urban expansion. Urbanization took place mainly at the expense of fertile agricultural lands and sparse short vegetation. Oran is located in a semi arid region bordered by the Sahara desert to the south and the Mediterranean to the north. Its climate is characterized by moderately wet and cool winters and dry and warm summers. The annual climatological precipitation is less than $400 \mathrm{~mm}$ occurring mostly between October and May while monthly mean temperatures range between $5^{\circ} \mathrm{C}$ to $15^{\circ} \mathrm{C}$ in winter 
and $15^{\circ} \mathrm{C}$ to $30^{\circ} \mathrm{C}$ in summer (WMO). The vegetation cover is sparse and has undergone a severe degradation during the last couple of decades.

A Multispectral ETM+ image with a spatial resolution of $28.5 \mathrm{~m}$ is used to characterize the city's land cover in 2002 . The image centered at $35^{\circ} 39^{\prime} \mathrm{N}, 0^{\circ} 43^{\prime} \mathrm{W}$ has been reprojected and re-sampled to $25 \mathrm{~m}$. The re-sampled image has $1280 \times 810$ pixels and covers an area about $32 \times 20 \mathrm{~km}^{2}$ (figure 1).

\section{b. Land use map}

Land use over the study region is characterized by sparse distribution of evergreen needleleaf trees, grassland, shrubs with bare soil, bare soil, agriculture/C3-grassland with winter wheat, and urban land. Each of these land use types has been co-registered to one of the Simple Biosphere model SiB2 of Sellers et al. (1996a) vegetation classes (Table 1). The Urban type, labeled class 8 in this study, has been assigned SiB2 class 9 (shrubs/bare soil) morphological, physiological and optical properties with the following modifications: Urban classes comprise some vegetation mixture within the impervious surface, and are assigned the lowest NDVI value obtained from the surrounding class 9 and the lowest value for the maximum photosynthetic capacity; a higher soil reflectance obtained as an average from impervious surfaces with similar themes collected from literatures (Akbari 2002); rougher surface elements and a superficial soil layer completely impermeable to water with a maximum water holding capacity set to $2 \mathrm{~mm}$. Interlayer water transfer is not allowed in the soil profile of an urban pixel and any intercepted water beyond this threshold is expelled as surface runoff. As defined the 
urban class is the closest representation of the landscape since at this resolution we could not resolve pure impervious fractions.

When dealing with complex land use configuration, standard classification schemes using only radiometric information often fail to provide an accurate representation of the landscape (Haralick et al. 1973; Emran et al. 1996). An efficient scheme for improving classification without using ancillary data can be achieved by exploiting the image spatial heterogeneity (Mirmehdi and Petrou 2000; Simard et al. 2000). In this study, spatial information is characterized using texture-color features derived by an integrative scheme using wavelet transform (Safia et al. 2006). Based on training and verification sites taken over the region (Iftene and Safia 2004), a supervised classification scheme using radiometric and texture-color channels as described in (Safia et al. 2006) is carried out. The overall classification skill obtained for this study is $96.6 \%$; results of the classification are shown in Figure 2.

The ETM+ derived land use map at $25 \mathrm{~m}$ was then aggregated to $250 \mathrm{~m}$ and co-registered to the same projection as the NASA's Moderate Resolution Imaging Spectroradiometer (MODIS) products in order to use these products as input for the calculation of the morphological and phenological parameters necessary for $\mathrm{SiB} 2$ model. This was achieved using 10x10 non overlapping moving windows. For each new grid cell at 250 $\mathrm{m}$, we carry over statistics of existing land cover types at $25 \mathrm{~m}$ and express them as percent of the total number of types contained in the $250 \mathrm{~m}$ grid cell. This produced a multi-dimensional land use map at $250 \mathrm{~m}$ horizontal resolution containing the fraction of each type within the $250 \mathrm{~m}$ grid cell. 


\section{Model}

We use the Simple Biosphere model (SiB2) of Sellers et al. (1996a) to assess the impact of urbanization on local climate. $\mathrm{SiB} 2$ is a biophysically based soil vegetation transfer model that computes the exchanges of carbon, energy, water and momentum between the land surface and the atmosphere accounting for 12 vegetation types. The model also accounts for hydraulic and thermal properties of different soil types. The model predicts the canopy, ground and deep soil temperatures, the water content in 3 soil layers and the canopy stomatal conductance. It includes a coupled photosynthesisconductance sub-model to simultaneously compute the exchanges of carbon and water vapor between the leaf and the canopy air space (Collatz 1992). Photosynthesis is estimated using the fraction of photosynthetically active radiation (FPAR) absorbed by the canopy. FPAR is derived from satellite observations (Sellers et al. 1996b). The diffusion of water vapor from the leaf interior to the atmosphere (transpiration) during photosynthesis is controlled by stomatal conductance. Stomatal conductance depends on the carbon assimilation rate, which in turns depends on the amount of soil moisture available in the plants' root zone, as well as atmospheric conditions (Sellers et al., 1996a). The roughness length is computed based on land cover type, canopy architecture and leaf density- the leaf area index (LAI) (Sellers et al. 1985). The land surface model uses a two-stream approximation to estimate surface reflectance in the visible and nearinfrared wavelengths (Sellers et al. 1985). The snow-free albedo depends on leaf and soil reflectances, which vary with vegetation and soil type, respectively. In addition to the biophysical fields describing the vegetation phenology, $\mathrm{SiB} 2$ is driven by short- and longwave radiation, large scale- and convective precipitation, and the temperature and wind 
speed at the canopy level; it returns the emitted and reflected radiation fluxes, the soil and canopy latent and sensible heat fluxes and the carbon assimilation rate, as well as many other diagnostics.

The model is run in a stand alone mode where the atmospheric drivers are obtained from observations and fed to the land surface model. In a stand-alone mode it is possible to 1) isolate the effects of land cover change on local near-surface climate independent of the atmospheric circulation and 2) run the model over a limited area at high spatial resolution $(250 \mathrm{~m} \times 250 \mathrm{~m})$ using fractional vegetation cover aggregated from a $25 \mathrm{mx} 25 \mathrm{~m}$ resolution to adequately describe the observed land cover changes and their impact on surface climate. Results obtained using the model forced by observations can be found in (Zhang et al. 1996; Bounoua et al. 2004; Bounoua et al. 2006).

\section{1). BIOPHYSICAL FIELDS}

The Model biophysical data are derived from satellite observations using MODIS products. FPAR and LAI are not routinely produced by the MODIS processing chain at $250 \mathrm{~m}$. In this study, we use the MODIS NDVI data (MOD13Q1) at $250 \mathrm{~m}$ horizontal resolution and 16-day composite along with the land use map developed for the study region to derive FPAR and LAI using a modified version of the Sellers (1996b) algorithm. The modified algorithm has a new set of tunable parameters describing the 5th and 95th percentiles for NDVI used in the intermediate computation of the simple ratio and different maximum and minimum LAI values for each biome type and its stem area index. The modification of these parameters compensates for the lack of sensitivity of the AVHRR sensor, for which the algorithm was built, compared to MODIS. When 
biome-averaged over the study domain and aggregated to $1 \mathrm{kmx} 1 \mathrm{~km}$ grid, LAI values obtained using this algorithm, closely match those provided by the MODIS operational algorithm at $1 \mathrm{kmx} 1 \mathrm{~km}$ over the same region. Fields of FPAR, LAI, greenness fractions, bulk aerodynamic resistances for vegetation, and roughness length are then computed at 16-day interval for each of the vegetation classes.

\section{2). SOIL AND ATMOSPHERIC DATA}

The soil map is based on the Food and Agricultural Organization (FAO) soil data (FAO 1997) at $4 \mathrm{~km}$ resolution. Soil texture is generated using the 9 soil classes defined by Zobler (1986) and soil properties are derived from Clapp and Hornberger (1978) for each of the soil texture class following Sellers et al. (1996b). Since the study region is small, soil types did not exhibit important variations. The slope factor was computed using local topography at $250 \mathrm{~m}$. The atmospheric drivers are obtained from the ECMWF-analysis for the year 2002 and interpolated to 1 hour time step from their original 3-hourly resolution. The data consists of surface short and longwave diffuse and direct radiation, surface wind speed, air temperature and large scale and convective precipitation. Since the study area is small, we apply the same atmospheric forcing to the entire region. Statistics compiled from these drivers are consistent with local precipitation and temperature climatology reported by (WMO)

\section{Model simulations}

The land use maps and their associated biophysical fields were used as surface boundary conditions to drive $\mathrm{SiB} 2$. In $\mathrm{SiB} 2$, canopy and ground temperatures are rather fast response variables and their spin up to equilibrium is relatively fast. In this study, 
they are initialized using the initial surface temperature from the drivers. The canopy and ground interception stores are initialized using climatological values obtained from the Colorado State University general circulation model (Randall et al. 1996), which hosts $\mathrm{SiB} 2$ in coupled mode. The initialization of soil moisture is generally the most problematic as the three soil layers need to be in equilibrium with the atmospheric drivers and the vegetation density. Over the study region, observations of soil moisture are rare. The initialization is done iteratively using FPAR (Stephanova 2001) based on the logic that vegetation density is in quasi-equilibrium with climate and the amount of soil water. FPAR is directly related to the amount of green vegetation and its value is a close indication of the amount of soil water available for the vegetation.

Six different simulations were conducted; one for each land cover type defined in table 1. Each simulation starts from the same initial conditions and runs forward for 10 years. The simulations differ in the vegetation type, vegetation attributes and the associated annual cycle of the vegetation phenology. All model simulations are performed at $250 \mathrm{mx} 250 \mathrm{~m}$ and hourly time step using the same climate drivers so that the model responses are exclusively attributable to land cover change. The use of the land surface model in an off-line mode does not account for atmospheric feedback and therefore allows isolation of the effects of landscape differences on local near surface climate conditions. The analysis is done using outputs averaged over the last three annual cycles, neglecting the first seven years to account for model spin up.

\section{Results and Discussions}


In a previous study, Bounoua et al. (2006) indicated that in heterogeneous landscapes the aggregation of the land cover from higher resolution to a single dominant type resulted in significant uncertainties that can propagate down to the surface climate variables. In this study, the model is run separately for each land cover type assumed to occupy the entire $250 \mathrm{~m}$ grid cell and results from the different model simulations are presented for separate land cover classes as well as a weighted average obtained as response from each class weighted by its fraction within the $250 \mathrm{~m}$ grid cell.

\section{a. Diurnal response}

\section{1). CARBON AND ENERGY}

Hourly time series of physiological and climate variables for select locations were saved for the entire annual cycle and seasonal composite diurnal cycles were constructed. In the following discussion, we present detailed responses for all land cover types for some key variables during winter (DJF) and summer (JJA), over a grid cell centered around $\left(35^{\circ} 37^{\prime} 23^{\prime \prime} \mathrm{N} ; 0^{\circ} 40^{\prime} 25^{\prime \prime} \mathrm{W}\right)$. This grid cell is representative of the study region as it is composed of a mix of all land cover types listed in table 1. The fractional coverage of the different classes in the grid cell as well as the maximum photosynthetic capacities per leaf area $(V \max )$ and FPAR for each vegetation type are listed in table 2.

Photosynthesis depends in large part on FPAR and on Vmax of the leaves on the canopy. This cropland dominated point has larger FPAR values in winter than in summer, mostly due to winter crops and seasonal grass. However, winter, assimilation rates are inhibited by cold temperatures. During summer, assimilation rates are almost twice those of winter for all vegetation classes. The responses of the different land cover classes to the same atmospheric forcing is different among classes and between seasons (Figure 3). 
During the cold season (DJF), most of the land cover classes have a 'bell shaped' assimilation response except for classes 7 and 11. These two classes for which assimilation is inhibited at around $10^{\circ} \mathrm{C}$ (Sellers et al. 1996a) have a winter active diurnal cycle only between about 11 am and $5 \mathrm{pm}$ local time when the simulated canopy temperature reaches values higher than $10^{\circ} \mathrm{C}$. For these classes, the peak photosynthesis rate is about $1.8 \mu$-moles. $\mathrm{m}^{-2} \cdot \mathrm{s}^{-1}$. Photosynthesis affects stomatal conductance which in turn controls the transpiration flux. Stomatal conductance is also affected by atmospheric $\mathrm{CO}_{2}$ concentration, canopy air space relative humidity, leaf area density and a biome dependant parameter characterizing the carbon pathway either as $\mathrm{C}_{3}$ or $\mathrm{C}_{4}$. These short groundcover vegetations appear to be well adapted to local climate and soil of this semiarid region. They are $\mathrm{C}_{4}$ plants and are more water use efficient than their $\mathrm{C}_{3}$ counterparts (e.g., cropland). For about half the amount of water lost to transpiration, $\mathrm{C}_{4}$ vegetation assimilates about the same amount of carbon as the $\mathrm{C}_{3}$. These biomes are also drought resistance and do well in temperatures ranging between approximately $10^{\circ} \mathrm{C}$ and $40^{\circ} \mathrm{C}$. They take advantage of the fall to late spring precipitations and mild temperatures and are able to maintain some photosynthetic rate during summer droughts. The shrubby vegetation (type 9) is also a $\mathrm{C}_{4}$ plant native to the region; its peak assimilation rate during the winter is $2.84 \mu$-moles. $\mathrm{m}^{-2} \cdot \mathrm{s}^{-1}$, slightly higher than those of types 7 and 11 , mainly because of higher $V \max$ (Table 3). With about the same values of FPAR and Vmax as the shrubby vegetation (type 9), the photosynthetic rate of the $C_{3}$ needleleaf evergreen biome (type 4) during winter is only $2.28 \mu$-moles. $\mathrm{m}^{-2} \cdot \mathrm{s}^{-1}$; lower than that of the short vegetation (type 9). This is partially attributable to the different carbon pathways between the two types and a different sensitivity to low temperatures. Since 2002 is a normal 
climatological year for the region, the low photosynthetic rate for the needleleaf tree suggests that this biome is not well adapted to the region.

Biome type 4 is composed mostly of pines trees, Pinus Halepensis Mill., (Boulli et al. 2001) known to have a lower productivity than other trees from the same species in the Mediterranean region (Michelozzi et al. 2004). Among all land cover classes co-existing in this grid cell, cropland (type 12) has the highest photosynthetic capacity per leaf area and resulted in peak photosynthetic rate of $3.75 \mu$-moles. $\mathrm{m}^{-2} . \mathrm{s}^{-1}$ during the winter season. In this region, croplands include winter wheat which constitutes a large part of the agricultural practice. Crop rotation is also widely used and includes other types of leafy winter crops such as cardoons (Cynara Cardunculus L.) and other cool season crops of the same family as cauliflower (Brassica oleracea var. botrytis) (Figure 4).

The optimal time for winter wheat and barley planting in the region occurs between MidNovember and Mid-December. As expected, photosynthesis is insignificant for the urban class because of lack of vegetation (not shown). For all land cover types, the stomatal conductance is a mirror image of the net photosynthesis and has reached a maximum of $1.62 \mathrm{~m} \cdot \mathrm{s}^{-1}$ for the cropland.

During the summer months (JJA) the diurnal course of the physiological activity of the different land cover classes is similar to that of winter except that the narrow window of photosynthetic activity of biomes 7 and 11 is much wider. For all land cover classes, the photosynthetic rates are approximately twice those of winter. The peak photosynthesis occurs earlier in the day, especially for biome 4 which experiences a high temperature stress in mid-morning. The high-temperature stress describes the degree to which the photosynthetic capacity is scaled down due to high-temperature effects on physiological 
activity. It depends on the simulated canopy temperature and other vegetation type dependent parameters. Canopy temperatures are to a large extent determined by the climate; however the extent to which local temperatures change is modulated by the physiological state of the vegetation and its interaction with climate (Bounoua et al. 1999; Bounoua et al. 2000). The level of high temperature stress affecting type 4 during summer is further evidence that this species is not well adapted to local climate. Statistics of the diurnal variation of canopy assimilation and conductance rates for all cover types during summer are summarized in table 3.

Daily statistics describing the temperature response for summertime (JJA) are shown in Table 4. Remarkably, the diurnal temperature maxima are not much different between land cover types. Differences among all short vegetation types are relatively small and do not exceed $0.4^{\circ} \mathrm{C}$. However, the urban class resulted in warming in excess of $1^{\circ} \mathrm{C}$ over all other classes and reached a maximum of $34.70^{\circ} \mathrm{C}$; an additional warming of only $1.45^{\circ} \mathrm{C}$ above the $33.25^{\circ} \mathrm{C}$ simulated for the needleleaf trees. This result is counterintuitive and to some extent different from that obtained in previous urbanization studies in temperate climates. Previous studies revealed a marked summertime temperature difference between the urban and surrounding non urban (vegetated) lands referred to as the 'Urban Heat Island' effect (Quattrochi et al. 1996; Shepherd et al. 2002). Our results indicate that in this semi-arid region where vegetation is sparse and composed of drought resistant species, this contrast is not so sharply marked; because in these regions, even when the soil is not built up, it is either bare or covered with short vegetation that leaves it exposed to solar radiation. In these bare or otherwise sparsely vegetated areas, soil is severely degraded but is still characterized by a surface reflectance 
lower than that recorded in urban areas. This result is in line with those of Shepherd (2006). From a radiative perspective, during summer when the ground is bare and dry, these soils behave like urban impervious surfaces; most of the absorbed solar energy is restored as sensible heating in just about the same way as in urban areas; thus reducing the horizontal temperature gradient between urban and non urban areas. In contrast, in temperate climates urban areas are surrounded by dense vegetation and the lack of evaporation forces the redistribution of absorbed solar energy into ground absorption and sensible heating. In surrounding non-urban regions, vegetation: 1) intercepts and reevaporates precipitation at potential rates and 2) extracts water from deep soil and diffuses it to the atmosphere during the process of photosynthesis, thus keeping the surrounding regions cooler than the urban center.

These vegetation effects are not as important in semi-arid lands during summertime. Canopy cover in these regions is sparse, which limits evaporational cooling at the landscape scale. Where trees do exit, their physiological activity is inhibited by high summer temperatures and no interception occurs due to lack of summer rainfall. This landscape configuration, combined to the seasonality of the climate, creates an asymmetry in the diurnal cycle over semi-arid regions. For example, the difference in temperature maxima between the urban class and the evergreen forest is $1.45^{\circ} \mathrm{C}$ (Table 4) while the difference between their minima is only $0.81^{\circ} \mathrm{C}$, clearly indicating that the urban maximum increases much more than the minimum temperature. This asymmetry in the diurnal temperature cycle is a direct consequence of the lack of evapotranspiration in the urban class during the day. 
Figure 5 shows the diurnal cycle of the coolest class (type 4), the urban class (type 8) and the weighted average temperature - the temperature apparent to the large scale atmospheric motion - which includes contributions from all classes. During nighttime, the simulated urban temperature is slightly higher than that of the weighted average, however during the course of the morning when radiative forcing intensifies, the urban class warms faster; and this continues until the maximum insulation is reached around $1 \mathrm{pm}$ local time. In the mid-afternoon, the vegetation is stressed and the stomates close causing the temperature to be higher than that reached in the urban class.

These results suggest that vegetation can modulate the local diurnal temperature cycle and may play an important role in regional climate. In instances of low soil moisture or when the atmospheric humidity is limiting, declining photosynthesis leads to reduced stomatal conductance and lowers transpiration. Where this happens, temperature increases. It is thus reasonable to speculate that the projected future potential temperature rise and precipitation reduction in the Mediterranean region associated with anthropogenic $\mathrm{CO}_{2}$ increase (IPCC 2007) may have an adverse effect on long-term productivity of this region's vegetation and can exacerbate surface warming above and beyond the radiative forcing effect.

\section{2). HYDROLOGY}

The hydrological module of $\mathrm{SiB} 2$ partitions the incoming precipitation into canopy interception and throughfall (precipitation not intercepted by the canopy). The canopy interception can either evaporate at the potential rate or contribute to the throughfall when the canopy holding capacity is exceeded. The combination of direct 
throughfall and water dripping from the canopy is added to the ground liquid water store. There, the water can either evaporate or infiltrate into a shallow $(2 \mathrm{~cm}$ for all vegetated lands) surface layer if the ground storage capacity is exceeded. If the infiltration rate is in excess of the infiltration capacity of the soil, the excess water contributes to surface runoff. Similarly, water from the surface layer can either evaporate or infiltrate into the root zone layer from which it can flow up back to the surface layer, infiltrate into the deep layer, be used by plants for transpiration, or contribute to runoff. From the deep soil layer, water can diffuse up to the root zone or contributes to runoff through gravitational drainage.

We describe the evolution of the surface runoff during June and March, the closest months to summer and winter, respectively with substantial rainfall over the region. For the urban areas the shallow surface layer saturates at $2 \mathrm{~mm}$ and no interlayer water transfer is allowed between the surface and the other two soil water stores.

During June, the only summertime month with precipitation (about $27.5 \mathrm{~mm}$ ), runoff (not shown) is null for all vegetated classes. This was expected as most of the rain water is used to replenish the depleted soil water stores. In contrast, for the urban class, about half of the rain water (49\%) is expelled as surface runoff. Figure 6 shows the daily composite precipitation, surface runoff and soil moisture content in the surface layer during the month of March. The daily composite precipitation shows rainfall events partitioned over the entire day with a surface layer constantly saturated due to frequent large scale precipitation. Of the $51.4 \mathrm{~mm}$ of rain received during this month, about $57 \%$ (29.3 $\mathrm{mm})$ went into surface runoff. This ratio of runoff to precipitation is relatively high and could cause flashfloods. Flashfloods are frequent and violent in Oran and elsewhere in most 
cities of Algeria, especially during winter. In November 2007, a flashflood following torrential rains killed several people and resulted in heavy damage in several cities in Algeria including Oran (El Watan, 2007). For a large part, causes of damages are related to land use management. Our simulated composite results for the month of November indicate saturation of the surface layer for an average daily precipitation of about $1.2 \mathrm{~mm}$.

\section{$b$ Monthly response}

\section{1). TEMPERATURE}

As seen from the diurnal data, the characteristic response of the vegetation physiology tends to dominate when vegetation is active. This is not necessarily the case outside the growing season. In this semi-arid region, the growing season is not clearly defined as in temperate latitudes; the temperature and precipitation are out of phase and when precipitation reaches its peak in spring, the temperature is still relatively cold and partially inhibits vegetation growth. The maximum monthly precipitation is generally received in April (Figure 7), when the monthly mean temperature is less than $15^{\circ} \mathrm{C}$. Temperatures between $15^{\circ} \mathrm{C}$ and $20^{\circ} \mathrm{C}$, suitable for vegetation growth, last only for a short period between May and June. Soon after, between July and September, monthly mean temperatures reach much higher values with no rain (Figure 8).

This particularity in the climate seasonality and its interaction with vegetation leads to a unique annual temperature response for urban areas. Figure 9 shows monthly temperatures differences between the urban class and the average of all other land cover classes, averaged over the entire domain. From about October to March, our simulated results show that the vegetated land is slightly warmer than the urban class; the inverse is 
obtained during summer months. The particularity of this response comes from the fact that the urban albedo is higher than that of the surrounding regions. The difference between the surface energy budgets of the urban and non urban areas is thus largely modulated by albedo and transpiration. These two factors may either work in tandem or offset each other depending on the season. During summer, the lack of evaporation and its associated warming dominates the cooling effect of high albedo in urban areas compared to non urban areas which still maintain some transpiration. During the winter however, in addition to high albedo, urban soils are exposed and evaporation takes place at potential rate; thus exacerbating the cooling compared to non urban areas in which transpiration is limited by cold temperatures, thus shunting most of the absorbed energy into sensible heating. These results are consistent with urban studies over other arid regions which showed urban areas exhibiting a relatively weak urban heat island and sometimes even being a heat sink when evaporation is important (Shepherd 2006) Although not very active over the region, the vegetation physiological activity plays an important role in the control of surface temperature, resulting in a less marked temperature contrast between urban and non urban areas. The monthly mean temperature difference shows the urban areas warmer by about $0.35^{\circ} \mathrm{C}$ during summer and cooler by about the same amount during winter compared to non urban lands. An effect seemingly typical of semi-arid regions since in temperate latitudes, typical temperature difference between urban and non-urban areas during summers is around $3^{\circ} \mathrm{C}$ (e.g.; Oke et al., 1999). 
The spatial distribution of the simulated monthly mean temperature for the summer (JJA) is shown in figure 10. The simulated temperature shows that urbanization contributes a monthly mean warming up to $1.16{ }^{\circ} \mathrm{C}$ during the summer months.

\section{2). CARBON}

Our results show that in Oran, a typical semi-arid city with significant economic development, carbon uptake from vegetated lands is not important. However, urbanization is poised to grow and may alter the carbon cycle in this fragile ecosystem. The rate of change in atmospheric $\mathrm{CO}_{2}$ concentration is indicative of the balance between $\mathrm{CO}_{2}$ emission and removal processes. Atmospheric carbon sequestration is an important climate change issue, especially for those developing economies, such as Oran whose climate is projected to be negatively affected by future increase in greenhouse gases. As anthropogenic carbon emissions continue to increase precipitation are expected to decline and temperature to rise over the entire Mediterranean region (IPCC 2007). It is thus relevant to assess and quantify the capacity of the terrestrial vegetation to sequester carbon. The city of Oran is relatively small compared to the total area of the country; however its landscape is representative of the long narrow strip along the Mediterranean cost which hosts about $80 \%$ of the country's population.

The total annual amount of carbon uptake from all land cover types is about $1.9410^{6}$ metric tons of carbon (Table 5).

About $0.2310^{6}$ metric tons are assimilated during the months of April, May and June, hereafter referred to as the rainy season, and $1.710^{6}$ metric tons is assimilated during the remainder of the year. The widespread shrubby vegetation (type 9) has the largest annual 
carbon uptake of $0.6210^{6}$ metric tons, $89 \%$ of which takes place outside of the rainy season. The amount of carbon assimilated during the rainy season is small for all land cover types, suggesting that in this semi-arid region seasonality has an important effect on the relatively weak carbon cycle. Croplands have the second largest assimilation rates followed by tall trees (type 4). Overall, tress and cropland contribute $46 \%$ of the carbon uptake while grasslands and other shrubs encroachment take up 56\%. However, from the total current gross carbon uptake, only about $2 \%$ is sequestrated in land after accounting for heterotrophic respiration (William H., 1991) leading to a relatively small annual terrestrial carbon sink of only $0.0410^{6}$ metric tons for the entire region.

The small amount of carbon sequestrated by this relatively fertile land and the continuous expansion of the urban area expected in near future lead to two plausible possibilities: 1) urban expansion continues at the expense of fertile lands-business as usual or 2) urban expansion continues but blended within regionally adapted vegetations to mitigate the local warming and accelerate carbon recycling-smart growth. We considered these two hypotheses and carried out a range of modeling scenarios to: 1) quantify the impact of a 'business as usual' urban expansion and 2) assess to what extent can vegetation mitigate the urban warming and contribute to increasing the carbon uptake in the study region. In the first scenario (scenario 1), we assume urbanization will continue to expand to reach $50 \%$ of the total study area expanding equally on the available land, excluding forests (Table 6).

Where this happens, evapotranspiration decreases and exacerbates the warming. However, because the short vegetation surrounding the city in this semi arid region is as dry and warm as the city itself, the impact on surface temperature is not significant. For 
example, the warmest month (July) mean temperature increased only by a small fraction compared to the current situation (control) and the annual total carbon uptake decreased by $0.6810^{6}$ metric tons (Table 7).

In a second scenario (scenario 2), we examined to what extent can vegetation mitigate warming. We run an additional model simulation similar to those described above but where new vegetation was introduced to the area. The new vegetation is a platane tree species (Platanus algeriensis), a species which exists in the region and whose morphological and physiological characteristics have, to some extent, acclimated to local environment. The platane, a tall broadleaf deciduous tree, is assigned $\mathrm{SiB} 2$ class 2 (Sellers et al. 1996a) with slight modifications to its characteristics, set to match field observations (Iftene and Safia 2004) and the local climate. Its canopy top and base heights are set to $20 \mathrm{~m}$ and $4 \mathrm{~m}$, respectively with an inflexion height for leaf area at 16 $\mathrm{m}$. Its physiology is modeled to resist canopy temperatures ranging between 15 and 42 ${ }^{\circ} \mathrm{C}$ and its root depth of $3.5 \mathrm{~m}$ allows it to extract water from deep soil layers. The characteristic parameterization of this tree is set to maximize photosynthesis during the spring and undergoes moderate temperature and water stresses during summer while keeping some physiological activity limited by mild temperatures during the fall. Feedback mechanisms whereby the growth of vegetation in unstressed conditions can act to maintain the precipitation has been demonstrated through modeling (Zeng et al. 2004). This scenario expanded the urban area to $50 \%$ of the total available land, just as in scenario 1 without altering the existing forested area (type 4), but replaced all short vegetation by the newly introduced platane tree $(27.15 \%)$ and kept about $7.12 \%$ of cropland area. Remarkably, despite the increase of $50 \%$ in urban area, the mean July 
temperature is cooler than the control by about $0.89^{\circ} \mathrm{C}$ and the carbon uptake increases by $0.7610^{6}$ metric tons (Table 7), or 39\% more than the current configuration. It is clear that this scenario is much more advantageous than scenario 1; it allows a reasonable urbanization growth, keeps a fraction of the land for agriculture and increases forested areas to a standard of about $20 \mathrm{~m}^{2}$ per capita, based on the 2005 population size of 1,034,000 for Oran (http://books.mongabay.com/population_estimates/full/OranAlgeria.html). Most importantly, it reduces the surface temperature by about $1^{\circ} \mathrm{C}$ and more than doubles the carbon uptake compared to scenario 1.

\section{Annual response}

The annual cycle of the vegetation physiology is dictated by the prevailing surface climate, mostly precipitation and temperature. In the following section we discuss the weighted average physiological and hydrological responses, over the selected grid cell discussed in section (IV) at the annual timescale and also compare the simulated domain averaged temperature response to available observations. The surface runoff (not shown) is insignificant over this grid cell which is only $1 \%$ urban. The intra-annual variation in precipitation is important and is mirrored in the water content of the surface layer (Figure 11). However, the precipitation variations are dampened as they make their way through the hydrological reservoirs. The water content in the root zone is depleted to below 0.25 only between August and September whereas the last significant precipitation of the season occurred on June $21^{\text {st }}$. This suggests that soil moisture inertia acts as a low pass filter transforming high frequency precipitation variations into low- 
frequency hydrological anomalies allowing thus deep rooted vegetation to maintain some level of transpiration long after the last precipitation.

The weighted domain averaged simulated seasonal temperatures are slightly lower than those observed at a single station in the study region (Figure 12). The model simulated summer temperatures are higher than observations by about $1.2{ }^{\circ} \mathrm{C}$ suggesting strong model sensitivity to vegetation and climate when water is limiting photosynthesis. Simulated temperatures are slightly lower than observations during spring and fall. However, at times the intra-annual variation is large enough to mask the difference between simulated and observed temperatures.

\section{Concluding Remarks}

Urbanization in the city of Oran, a small but in full economic development region has expanded about $17 \%$ during the last 50 years and is poised to grow in the future. Urban expansion took place mostly in bare or shrubby soils; however some of it has replaced fertile agricultural lands. Simulations using a land surface model that includes a coupled stomatal conductance photosynthesis sub-model are used to examine the effect of this urban expansion, as a form of land use, on surface climate in this semi-arid region. Several model runs were performed and compared to quantify the impact of each land cover type on the surface energy, water and carbon budgets from diurnal to annual timescales. Results show that the temperature and precipitation phases do not concur for the development of dense vegetation and potentially may, with a warming climate, lead to complete desertification of the region. Our analysis highlights some important physical processes, the contexts in which they occur and how those contexts may have already contributed to landscape degradation. Combined with previous research (Hermann and 
Hutchinson 2005), this study contributes to expand our understanding of the concept of land degradation and desertification, especially in regions adjacent to the large subtropical deserts.

Over this semi arid region, canopy physiological activity is limited both by cold temperatures during winters and by the lack of precipitation and high temperatures during summers. Urbanization in Oran is yet just another anthropogenic forcing on the already stressed native vegetation. Its impact seems small when viewed only from the scope of the fraction of land it actually occupies, however it is the most severe and permanent type of land degradation and generally takes places on fertile lands. Our analysis indicates that there is no sharp contrast in temperature between the urban and non urban area as in temperate climates and large amounts of runoff occur in urban areas during precipitation events, consistent with Oran's observed frequent and devastating flashfloods, during sustained rainfall.

We show through model simulations that if the city expands, as it has in the past, using equally the available land with short vegetation but excluding areas with trees, the temperature will not increase significantly although this may result in decreasing the carbon uptake by more than half million metric tons per year. We also show that urban expansion along with an increase in the fraction of vegetated area, through plantation of locally adapted trees, may help mitigate the warming and increase carbon sequestration while still allowing a healthy urban environment with an area of green space per capita exceeding international standards.

Cities present great economic advantages and reduce the otherwise excessive per capita land use. They also offer a nice living and working space in an economically and 
socially integrated environment. However, serious damage to the environment and therefore to people's health, water resources, sanitation and air pollution levels may occur if urbanization is not integrated in a comprehensive land cover and land use program. These problems are less acute at present time, especially in industrialized countries. However, in developing nations they already pose a clear danger. As we move into the new millennium, problems associated with urban growth and material requirement can no longer be ignored, especially in fast growing economies and particularly in semi-arid regions along the southern cost of the Mediterranean. A combination of urban expansion with the projected rise in anthropogenic $\mathrm{CO}_{2}$ increase (IPCC 2007) may have adverse effects on their fragile ecosystems and may exacerbate the surface warming to exceed that of the radiative forcing (Sellers et al. 1996c; Bounoua et al. 1999).

These dynamics between the water, carbon and energy are tightly linked and show strong dependence on land cover and land use change. For example, our simulations indicate that the large biomass of tall woody vegetation sequesters more carbon than short shrubby vegetation and reduces increases in temperature; however it also accelerates the recycling of water through evapotranspiration, thus reducing the surface runoff and the availability of surface fresh water. Addressing these seemingly conflicting objectives separately will likely cause policies to fail in developing a sustainable balance.

\section{References}

Akbari H., 2002 Shade trees reduce building energy use and CO2 emissions from power plants. Environmental Pollution, 116:S119-S126 
Boulli A, Baaziz M. and M'hirit O., 2001, Polymorphism of natural populations of Pinus halepensis Mill, In Morocco as revealed by morphological characters, euphytica, 00: 1-8

Bounoua L., Masek J., Tourre Y.M., 2006, Sensitivity of surface climate to land surface parameters: a case study using the simple biosphere model SiB2. Journal of Geophysical Research-Part D-Atmospheres 111:1-10

Bounoua L., DeFries R.S., Imhoff M.L., Steininger M.K. , 2004, Land use and local climate: a case study near Santa Cruz, Bolivia. Meteorology and Atmospheric Physics 86:73-85

Bounoua L., Collatz G.J., Los S.O., Sellers P.J., Dazlich D.A., Tucker C.J., Randall D.A., 2000, Sensitivity of climate to changes in NDVI. J Clim 13:2277-2292

Bounoua L., Collatz G.J., Sellers P.J., Randall D.A., Dazlich D.A., Los S.O., Berry J.A., Fung I., Tucker C.J., Field C.B., Jensen T.S. , 1999, Interactions between vegetation and climate: Radiative and physiological effects of doubled atmospheric CO2. J Clim 12:309324

Boughedaoui M., R. Kerbachi and R. Journard, 2008, On-board emission measurement of high loaded light-duty vehicles in Algeria. Journal of the air \& water Management Association, 56, 576-587 
Clapp R.B., Hornberger G.M. , 1978, Empirical equations for some soil hydraulic properties. Water Resources Research 14 (4): 601-604.

Collatz G. J., Ribas-Carbo M. and Berry J. A., 1992 Coupled PhotosynthesisConductance Model for leaves of C4 plants. Australian Journal of Plant Physiology 19:519-538

El Watan. Le Quotidien independent, Edition du 29 novembre 2007, available online at http://www.elwatan.com/spip.php?page $=$ article\&id article $=81729$

Emran A., Hakdaoui M., Chorowicz J.,1996, Anomalies on geologic maps from multispectral and textural classification: the bleida mining district (Morocco). Remote Sens. Environ 57:13-21

FAO 1997, Land resources evaluation and the role of land-related indicators, by W G Sombroek, in Land quality indicators and their use in sustainable agriculture and rural development. Land and Water Bulletin No. 5. Rome

Goetz S. J., Claire A. J., Stephen D. P., Andrew J. S., Dmitry V. and Robb K. W. ,2004, Integrated analysis of ecosystem interactions with land use change: the Chesapeake Bay watershed. R.S. DeFries, G.P. Asner and R.A. Houghton (Editors), Ecosystems and Land Use Change. American Geophysical Union, Geophysical Monograph Series, Washington DC. $263-275$ 
Grimmond C.S.B, T.S. King, F.D. Cropley, D.J. Novak, C. Souch, 2002, Local-scale fluxes of carbon dioxide in urban environments: methodological challenges and results from Chicago. Environmental Pollution 116, S243-S254.

Hafner, J., and S.Q. Kidder, 1999: Urban Heat Island Modeling in Conjunction with Satellite-Derived Surface/Soil Parameters. J. Appl. Meteor., 38, 448-465.

Haralick R.M., Shanmugam K., Dinstein I., 1973, Textural Features for Image Classification. IEEE Transactions on Systems, Man and Cybernetics SMC-3:610-621

Hermann S. M. and C. F. Hutchinson, 2005. The Changing Contexts of the Desertification Debate. Journal of Arid Environment 63: 538-555

Iftene T., Safia A.,2004, Comparison between co-occurrence matrix and wavelet transform for textural classification of SPOT'S HRV (XS) images. Télédétection 4:39-49

Imhoff L. M., L. Bounoua, R. Defries, W. T. Lawrence, D. Stutzer, C. J. Tucker and T. Ricketts, 2004: The consequence of urban land transformation on net primary productivity in the United States. Remote Sens. Environ. 89, 434-443

IN (2007) United Nations Population Information Network. United Nations. Press Release POP/918, 24/2/2005. Release available at http://www.un.org/News/Press/docs/2005/pop918.doc.htm 
IPCC, Intergovernmental Panel on Climate Change, Climate Change, 2007, The Physical Science basis. Summary for Policymakers. Contribution of Working Group I to the Fourth Assessment Report of the Intergovernmental Panel on Climate Change.

Kerbachi R., Boughedaoui M., Bounoua L., Keddam M., 2006, Ambient Air Pollution by Aromatic Hydrocarbons in Algiers Atmospheric Environment (Vol. 40, No. 21, 3995 4003.

Matthew C. Hansen and S. J. Goetz , 2005, Encyclopedia of Hydrological Sciences Part 5. Remote Sensing, John Wiley \& Sons, Ltd DOI: 10.1002/0470848944.hsa057. Article Online Posting Date: April 15, 2006

Michelozzi M., Tognetti R., Maggino F. and Radicati M.,2004, Seasonal variations in monoterpene profiles and ecophysiological traits in Mediterranean pine species of group “halepensis”. URL: http://www.sisef.it: 65-64.

Mirmehdi M., Petrou M., 2000, Segmentation of color textures. IEEE Trans Pattern Anal Mach Intell 22:142-159

Oke T.R. , R.A. Spronken-Smith, E. Jauregui, C.S.B. Grimmond, 1999, The energy balance of central Mexico City during the dry season. Atmospheric Environment 33 39193930 
Quattrochi D. A., M. G. Estes, JR., C. A. Laymon, W. L. Crosson, B. F. Howell, J. C. Luvall, D. L. Rickman: Urban Heat Islands, in Our Changing Planet; Ed. King D. M. , Parkinson C. L, Partington K and Williams R. G. Cambridge University Press.

Quattrochi D.A., Lam N. S-N, Qiu H-L and Zhao W. ,1996, Image Characterization and Modeling System (ICAMS): A geographic information system for the characterization and modeling of multiscale remote sensing data. In Scaling of Remote Sensing Data for GIS, D.A. Quattrochi and M.F. Goodchild, eds. Lewis Publishers, New York, NY

Quattrochi D.A., Ridd M.K., 1994, Measurement and analysis of thermal energy responses from discrete urban surfaces using remote sensing data. Int. J. Remote Sens. 15:1991-2002

Randall D.A., Dazlich D.A., Zhang C., Denning A.S., Sellers P.J., Tucker C.J., Bounoua L., Berry J.A., Collatz G.J., Field C.B., Los S.O., Justice C.O., Fung I. , Revised land surface parameterization (SiB2) for GCMs. Part III: The greening of the Colorado State University general circulation model. J Clim 9:738-763

Safia A., Belbachir M.F., Iftene T. ,2006, La transformation en ondelettes pour l'extraction de la texture couleur. Application à la classification combinée des images (HRV) de SPOT. Int. J. Remote Sens. 27:3977-3990 
Sellers P.J., Randall D.A., Collatz G.J., Berry J.A., Field C.B., Dazlich D.A., Zhang C., Collelo G.D., Bounoua L., 1996a, Revised land surface parameterization (SiB2) for atmospheric GCMs. Part I: Model formulation. J. Clim. 9:676-705

Sellers P.J., Los S.O., Tucker C.J., Justice C.O., Dazlich D.A., Collatz G.J., Randall D.A.,1996b, A revised land surface parameterization (SiB2) for atmospheric GCMs. II. The generation of global fields of terrestrial biophysical parameters from satellite data. $J$ Clim 9:706-737

Sellers P.J., Bounoua L., Collatz G.J., Randall D.A., Dazlich D.A., Los S.O., Berry J.A., Fung I., Tucker C.J., Field C.B., Jensen T.G., 1996c, Comparison of radiative and physiological effects of doubled atmospheric CO2 on climate. SCIENCE 271:1402

Sellers P.J., 1985, Canopy reflectance, photosynthesis and transpiration. International Journal of Remote Sensing 6:1335

Shepherd J.M., 2006, Evidence of urban-induced precipitation variability in arid climate regimes. Journal of Arid Environments, 67:607-628

Shepherd J.M. and Burian S. J. ,2003, Detection of Urban-Induced Rainfall Anomalies in a Major Coastal City. Earth Interactions, Weather-Climate Processes, Remote sensing, Cryosphere-Hydrosphere Processes 7: 1-14 
Shepherd J.M., Harold P., and Negri A. J., 2002, On Rainfall Modification by Major Urban Areas: Observations from Space-borne Radar on TRMM. Journal of Applied Meteorology, Weather-Climate Processes, Remote sensing, Cryosphere-Hydrosphere Processes 41: 689-701

Simard M., 2000, The use of decision tree and multiscale texture for classification. Geosciences and Remote Sensing, IEEE Transactions on 38:2310-2321

Stefanova L., 2001, Sensitivity of seasonal forecast to the parameterization of land surface processes. PhD Thesis, Department of Meteorology, Florida State University

William H. Schlesinger, 1991: Biogeochemistry: An Analysis of Global Change. Academic Press. 443 pp.

WMO: data available at World Weather Information Service, Climatological information based on monthly averages for the 30-year period 1976-2005. Data available http://www.worldweather.org/

Zeng N., Hales K., Neelin J.D., 2002 nonlinear dynamics in a coupled vegetationatmosphere system and implications for desert-forest gradient. J Clim 15:3474-3487

Zhang C., Dazlich D.A., Randall D.A., Sellers P.J., Denning A.S., 1996, Calculation of the global land surface energy, water and $\mathrm{CO} 2$ fluxes with an off-line version of SiB2. Journal of Geophysical Research 101:19061-19075 
Zobler L., 1986, A World Soil File for Global Climate Modeling. NASA Technical Memorandum, 87802 


\section{List of Figures}

FIG. 1. ETM+ image (2002) of the study area showing the city of Oran.

FIG. 2. ETM+ derived land cover classification at $25 \mathrm{~m}$ x $25 \mathrm{~m}$ resolution, for Oran (2002).

FIG. 3. Canopy assimilation (tick line) $\mu$. moles. $\mathrm{m}^{-2} \cdot \mathrm{s}^{-1}$ on the left axis and conductance

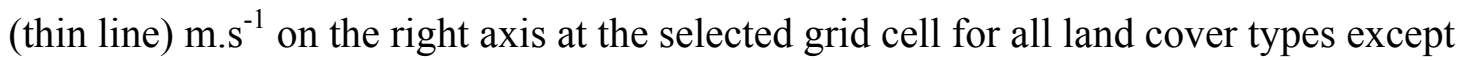
the urban type for which assimilation and conductance are insignificant. Left panel represents winter (DJF) and right panel summer (JJA).

FIG. 4. Farmers in a field harvesting tall leafy cardoons (Cynara Cardunculus L.) in preparation for wheat and barley planting; November 2007. The figure also depicts some sparse tree cover, bare soils and shrubs, characteristic of the landscapes over this semiarid region.

FIG. 5. Composite diurnal temperature cycles for the summer (JJA) for the selected grid cell.

FIG. 6. Daily composite precipitation (mm.hr-1), surface runoff (mm.hr-1) and surface layer soil moisture in the urban area (\% of saturation) for the month of March.

Precipitation and surface runoff are scaled by 100 for plotting purpose.

FIG. 7. Monthly mean observed precipitation ( $\mathrm{mm})$. 
FIG. 8. Monthly mean weighted average temperature (Celsius).

FIG. 9. Difference between the urban temperature and the average for all other classes, averaged over the entire domain. Positive values indicate warmer temperatures for urban areas compared to surroundings.

FIG. 10. A) The extent of the urban area at $25 \mathrm{~m} \times 25 \mathrm{~m}$ resolution (in white) and B) the simulated monthly mean surface temperature (JJA). The simulated temperature is resampled to $25 \mathrm{mx} 25 \mathrm{~m}$ for plotting purpose.

FIG. 11. Hourly evolution of simulated assimilation rate in $\mu$ moles. $\mathrm{m}^{-2} \cdot \mathrm{s}^{-1}$ (left axis), surface layer (GW1), root zone layer (GW2) soil moisture content in percent (right axis) and observed precipitation in $\mathrm{mm} \cdot \mathrm{hr}^{-1}$ (right axis).

FIG. 12. Five day running-mean observed temperature at a single station in the study area and the domain averaged weighted mean simulated daily temperature (Celsius) for 2002.

\section{List of Tables}

TABLE 1. Land use characterization. ( ${ }^{*}$ The urban class corresponds to a modified SiB2 class 9, see text for details).

TABLE 2. The different land cover types co-existing in the selected grid cell centered $\left(35^{\circ} 37^{\prime} 23^{\prime \prime} \mathrm{N} ; 0^{\circ} 40^{\prime} 25^{\prime \prime} \mathrm{W}\right)$, their fractional vegetation cover (\%), FPAR averaged over 
June July and August (JJA) and December, January and February (DJF) (Unitless) and the maximum photosynthetic capacity, $\operatorname{Vmax}\left(\mu\right.$ moles.m $\left.\mathrm{m}^{-2} \cdot \mathrm{s}^{-2}\right)$.

TABLE 3. Daily statistics for assimilation (assim) in $\mu$.moles. $\mathrm{m}^{-2} \cdot \mathrm{s}^{-1}$ and stomatal conductance (cond) in $\mathrm{m} \cdot \mathrm{s}^{-1}$ averaged for June, July and August (JJA), for all land cover types and for the weighted average. 'min' (absolute minimum), 'max' (absolute maximum), ‘mean' (daily mean), 'nmean' (nighttime mean) and 'dmean' (daytime mean). The fractional coverage for each land cover type is also shown.

TABLE 4. Canopy temperature $\left({ }^{\circ} \mathrm{C}\right)$ daily statistics obtained from June, July, August (JJA) composite diurnal cycles, for all land cover types and for the weighted average. 'min' (absolute minimum), 'max' (absolute maximum), 'mean' (daily mean), 'nmean' (nighttime mean) and 'dmean' (daytime mean), dtr (daily temperature range) and 'diff' is the difference between the urban maximum temperature and the absolute maximum temperature $(\max )$ for each type. The fractional coverage for each land cover type is also shown.

TABLE 5. Gross carbon uptake per land cover type and the weighted average in grams. The rainy season total represents the total carbon uptake for April, May and June. The rainy season ratio represents the carbon uptake during the rainy season as a percent of the annual total per land cover type. The land cover type ratio is the percent of the annual total for each land cover type over the annual weighted total for all types.

TABLE 6. Fractional coverage of each land cover type as a percent of the total vegetated land for the two scenarios (see text for details).

TABLE 7. July mean temperature and total annual gross carbon uptake simulated under the two scenarios (see text for details). 


\section{Tables}

TABLE 1. Land use characterization. (" The urban class corresponds to a modified SiB2 class 9 , see text for details).

\begin{tabular}{|l|l|l|l|l|l|l|l|}
\hline $\begin{array}{l}\text { Land Use } \\
\text { Type }\end{array}$ & Water & $\begin{array}{l}\text { Evergreen } \\
\text { needleleaf }\end{array}$ & Grassland & Urban & $\begin{array}{l}\text { Shrubs/ } \\
\text { bare soil }\end{array}$ & $\begin{array}{l}\text { Bare } \\
\text { soil }\end{array}$ & $\begin{array}{l}\text { Agriculture/C3 } \\
\text { grassland }\end{array}$ \\
\hline $\begin{array}{l}\text { SiB2 } \\
\text { classes }\end{array}$ & 0 & 4 & 7 & $8^{*}$ & 9 & 11 & 12 \\
\hline
\end{tabular}

TABLE 2. The different land cover types co-existing in the selected grid cell centered $\left(35^{\circ} 37^{\prime} 23^{\prime \prime} \mathrm{N} ; 0^{\circ} 40^{\prime} 25^{\prime \prime} \mathrm{W}\right)$, their fractional vegetation cover (\%), FPAR averaged over June July and August (JJA) and December, January and February (DJF) (Unitless) and the maximum photosynthetic capacity, $\mathrm{Vmax}\left(\mu\right.$ moles. $\left.\mathrm{m}^{-2} \cdot \mathrm{s}^{-2}\right)$.

\begin{tabular}{|l|l|l|l|l|l|l|l|}
\hline Land cover type & 4 & 7 & 8 & 9 & 11 & 12 & Weighted average \\
\hline $\begin{array}{l}\text { Fractional } \\
\text { coverage }\end{array}$ & 4 & 5 & 1 & 3 & 10 & 77 & 100 \\
\hline Vmax & 60 & 30 & 1 & 60 & 30 & 100 & NA \\
\hline FPAR (JJA) & 0.84 & 0.40 & 0.02 & 0.57 & 0.27 & 0.76 & 0.69 \\
\hline FPAR (DJF) & 0.98 & 0.99 & 0.02 & 0.97 & 0.99 & 0.99 & 0.99 \\
\hline
\end{tabular}

TABLE 3. Daily statistics for assimilation (assim) in $\mu$.moles. $\mathrm{m}^{-2} \cdot \mathrm{s}^{-1}$ and stomatal conductance (cond) in $\mathrm{m} \cdot \mathrm{s}^{-1}$ averaged for June, July and August (JJA), for all land cover types and for the weighted average. 'min' (absolute minimum), 'max' (absolute maximum), 'mean' (daily mean), 'nmean' (nighttime mean) and 'dmean' (daytime mean). The fractional coverage for each land cover type is also shown.

\begin{tabular}{|c|c|c|c|c|c|c|c|c|c|c|c|c|c|c|}
\hline Land use & \multicolumn{2}{|c|}{ Type 4} & \multicolumn{2}{|l|}{ Type 7} & \multicolumn{2}{|l|}{ Type 8} & \multicolumn{2}{|l|}{ Type 9} & \multicolumn{2}{|c|}{ Type 11} & \multicolumn{2}{|c|}{\begin{tabular}{|l|} 
Type 12 \\
\end{tabular}} & \multicolumn{2}{|c|}{ Weighted } \\
\hline \multirow{2}{*}{ Fraction } & \multicolumn{2}{|l|}{4} & \multicolumn{2}{|l|}{5} & \multicolumn{2}{|l|}{1} & \multicolumn{2}{|l|}{3} & \multicolumn{2}{|l|}{10} & \multicolumn{2}{|l|}{77} & \multicolumn{2}{|c|}{100} \\
\hline & Assim & Cond & Assim & Cond & Assim & Cond & Assim & Cond & Assim & Cond & Assim & Cond & Assim & Cond \\
\hline MIN & -0.59 & 0.32 & -0.22 & 0.48 & 0.00 & 0.00 & -0.78 & 0.24 & -0.21 & 0.38 & -0.90 & 0.24 & -0.78 & 0.27 \\
\hline MAX & 4.50 & 1.75 & 6.34 & 1.08 & 0.00 & 0.00 & 5.06 & 1.76 & 5.08 & 0.84 & 5.95 & 2.05 & 5.72 & 1.82 \\
\hline MEAN & 1.69 & 0.84 & 2.01 & 0.70 & 0.00 & 0.00 & 1.68 & 0.77 & 1.54 & 0.55 & 1.87 & \begin{tabular}{|l|}
0.89 \\
\end{tabular} & 1.82 & 0.83 \\
\hline NMEAN & -0.40 & 0.32 & -0.15 & 0.49 & 0.00 & 0.00 & -0.54 & 0.24 & -0.14 & 0.39 & -0.64 & 0.25 & -0.54 & 0.27 \\
\hline DMEAN & 3.78 & 1.35 & \begin{tabular}{|l|l|}
4.17 \\
\end{tabular} & 0.91 & 0.00 & 0.00 & 3.91 & 1.29 & 3.23 & 0.71 & 4.38 & 1.53 & 4.17 & 1.39 \\
\hline
\end{tabular}

TABLE 4. Canopy temperature $\left({ }^{\circ} \mathrm{C}\right)$ daily statistics obtained from June, July, August (JJA) composite diurnal cycles, for all land cover types and for the weighted average. 'min' (absolute minimum), 'max' (absolute maximum), 'mean' (daily mean), 'nmean' (nighttime mean) and 'dmean' (daytime mean), dtr (daily temperature range) and 'diff' is the difference between the urban maximum temperature and the absolute maximum temperature $(\max )$ for each type. The fractional coverage for each land cover type is also shown. 


\begin{tabular}{|l|l|l|l|l|l|l|l|}
\hline Land use & Type 4 & Type 7 & Type 8 & Type 9 & $\begin{array}{l}\text { Type } \\
11\end{array}$ & $\begin{array}{l}\text { Type } \\
12\end{array}$ & Weighted \\
\hline Fraction & 4 & 5 & 1 & 3 & 10 & 77 & 100 \\
\hline MIN & 18.87 & 19.08 & 19.68 & 19.18 & 19.09 & 19.18 & 19.17 \\
\hline MAX & 33.25 & 33.39 & 34.70 & 33.61 & 33.47 & 33.43 & 33.44 \\
\hline MEAN & 26.38 & 26.34 & 26.93 & 26.47 & 26.36 & 26.45 & 26.44 \\
\hline NMEAN & 24.09 & 23.88 & 24.18 & 23.92 & 23.87 & 24.08 & 24.04 \\
\hline DMEAN & 28.66 & 28.80 & 29.67 & 29.01 & 28.85 & 28.82 & 28.83 \\
\hline DTR & 14.38 & 14.32 & 15.02 & 14.43 & 14.38 & 14.25 & 14.28 \\
\hline DIFF & 1.45 & 1.31 & 0.00 & 1.09 & 1.23 & 1.27 & 1.26 \\
\hline
\end{tabular}

TABLE 5. Gross carbon uptake per land cover type and the weighted average in grams. The rainy season total represents the total carbon uptake for April, May and June. The rainy season ratio represents the carbon uptake during the rainy season as a percent of the annual total per land cover type. The land cover type ratio is the percent of the annual total for each land cover type over the annual weighted total for all types.

\begin{tabular}{|l|l|l|l|l|l|l|l|}
\cline { 2 - 8 } \multicolumn{1}{c|}{} & type 4 & type 7 & type 8 & type 9 & type 11 & type 12 & $\begin{array}{l}\text { Weighted } \\
\text { total }\end{array}$ \\
\hline Annual total & $3.98 \mathrm{E}+11$ & $1.88 \mathrm{E}+11$ & $0.00 \mathrm{E}+00$ & $6.20 \mathrm{E}+11$ & $2.38 \mathrm{E}+11$ & $4.93 \mathrm{E}+11$ & $1.94 \mathrm{E}+12$ \\
\hline $\begin{array}{l}\text { Rainy season } \\
\text { total }\end{array}$ & $5.66 \mathrm{E}+10$ & $2.26 \mathrm{E}+10$ & $0.00 \mathrm{E}+00$ & $6.81 \mathrm{E}+10$ & $2.55 \mathrm{E}+10$ & $6.14 \mathrm{E}+10$ & $2.34 \mathrm{E}+11$ \\
\hline $\begin{array}{l}\text { Rainy season } \\
\text { ratio }\end{array}$ & 14 & 12 & 0 & 11 & 11 & 12 & 12 \\
\hline $\begin{array}{l}\text { Land cover } \\
\text { type ratio }\end{array}$ & 21 & 10 & 0 & 32 & 12 & 25 & 100 \\
\hline
\end{tabular}

TABLE 6. Fractional coverage of each land cover type as a percent of the total vegetated land for the two scenarios (see text for details).

\begin{tabular}{|l|l|l|l|l|l|l|l|l|}
\cline { 2 - 9 } \multicolumn{1}{c|}{} & & & Type & Type & Type & & & \\
\multicolumn{1}{c|}{} & Type 4 & Type 7 & 8 & 9 & 11 & Type 12 & Platane & Total \\
\hline Control & 15.73 & 8.61 & 21.67 & 23.69 & 14.23 & 16.07 & 0 & 100 \\
\hline Scenario 1 & 15.73 & 1.53 & 50 & 16.6 & 7.15 & 8.99 & 0 & 100 \\
\hline Scenario 2 & 15.73 & 0 & 50 & 0 & 0 & 7.12 & 27.15 & 100 \\
\hline
\end{tabular}

TABLE 7. July mean temperature and total annual gross carbon uptake simulated under the two scenarios (see text for details).

\begin{tabular}{|l|l|l|l|}
\cline { 2 - 4 } \multicolumn{1}{c|}{} & $\begin{array}{l}\text { Control "Current } \\
\text { situation" }\end{array}$ & $\begin{array}{l}\text { Scenario 1 "Business as } \\
\text { usual" }\end{array}$ & $\begin{array}{l}\text { Scenario 2 "Smart } \\
\text { growth" }\end{array}$ \\
\hline $\begin{array}{l}\text { July mean } \\
\text { temperature }\end{array}$ & 29.44 & 29.57 & 28.55 \\
\hline $\begin{array}{l}\text { Annual } \\
\text { assimilation }\end{array}$ & $1.94 \mathrm{E}+12$ & $1.26 \mathrm{E}+12$ & $2.70 \mathrm{E}+12$ \\
\hline
\end{tabular}




\section{Figures}

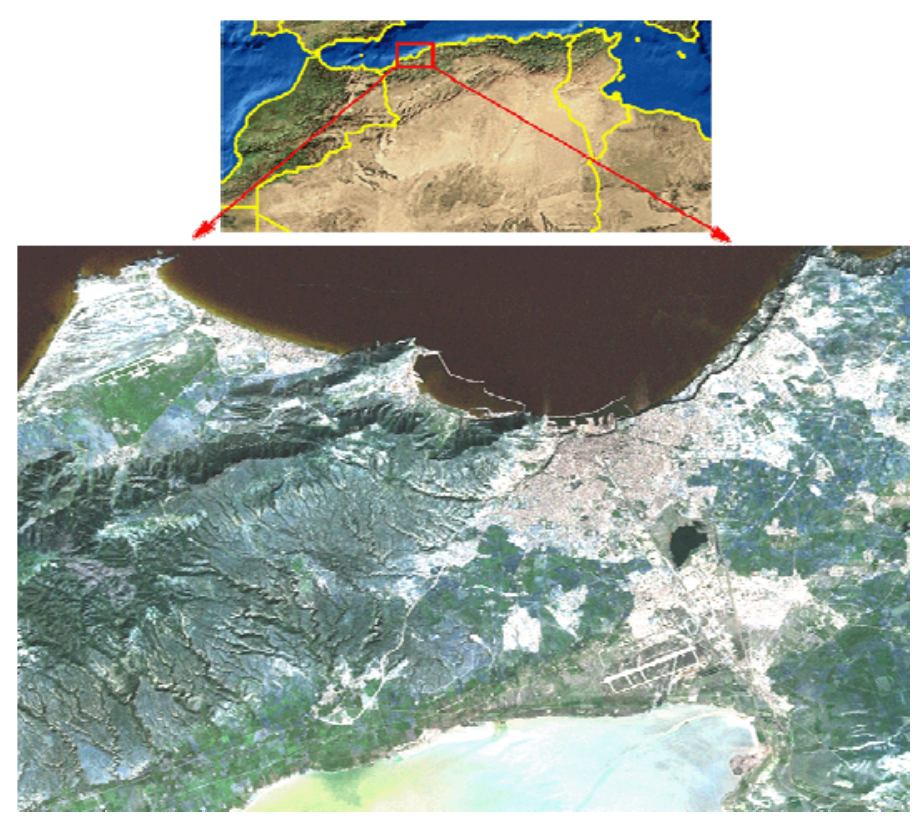

FIG. 1. ETM+ image (2002) of the study area showing the city of Oran

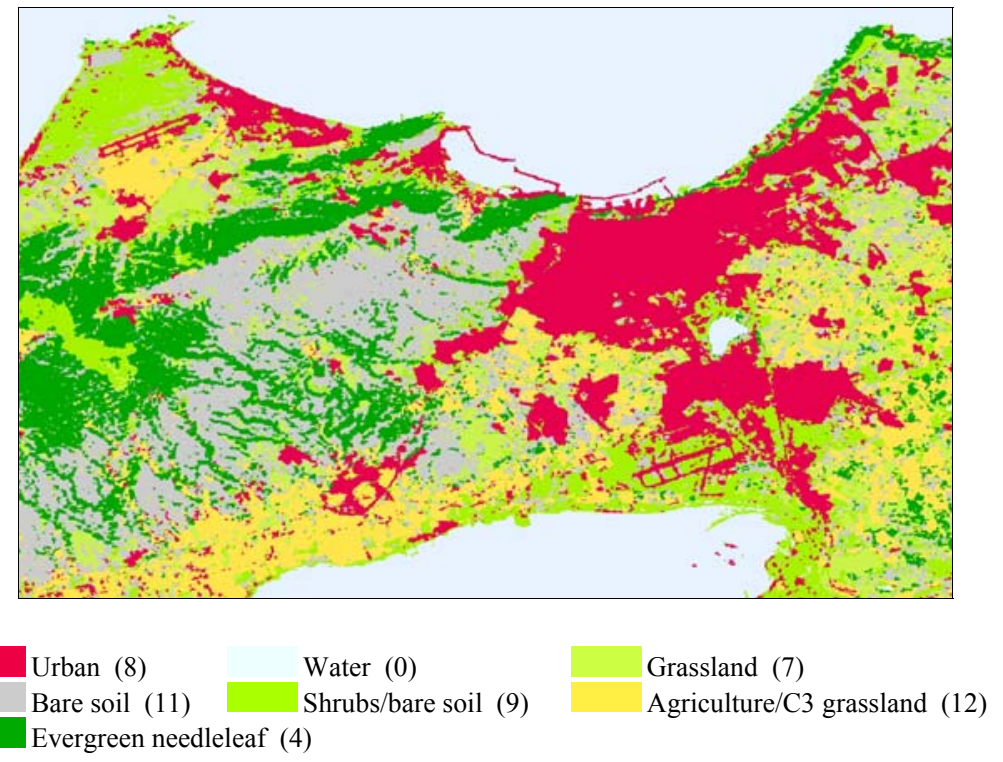

FIG. 2. ETM+ derived land cover classification at $25 \mathrm{~m} \times 25 \mathrm{~m}$ resolution, for Oran (2002). Numbers in parentheses represent the class code in the SiB2 model. 


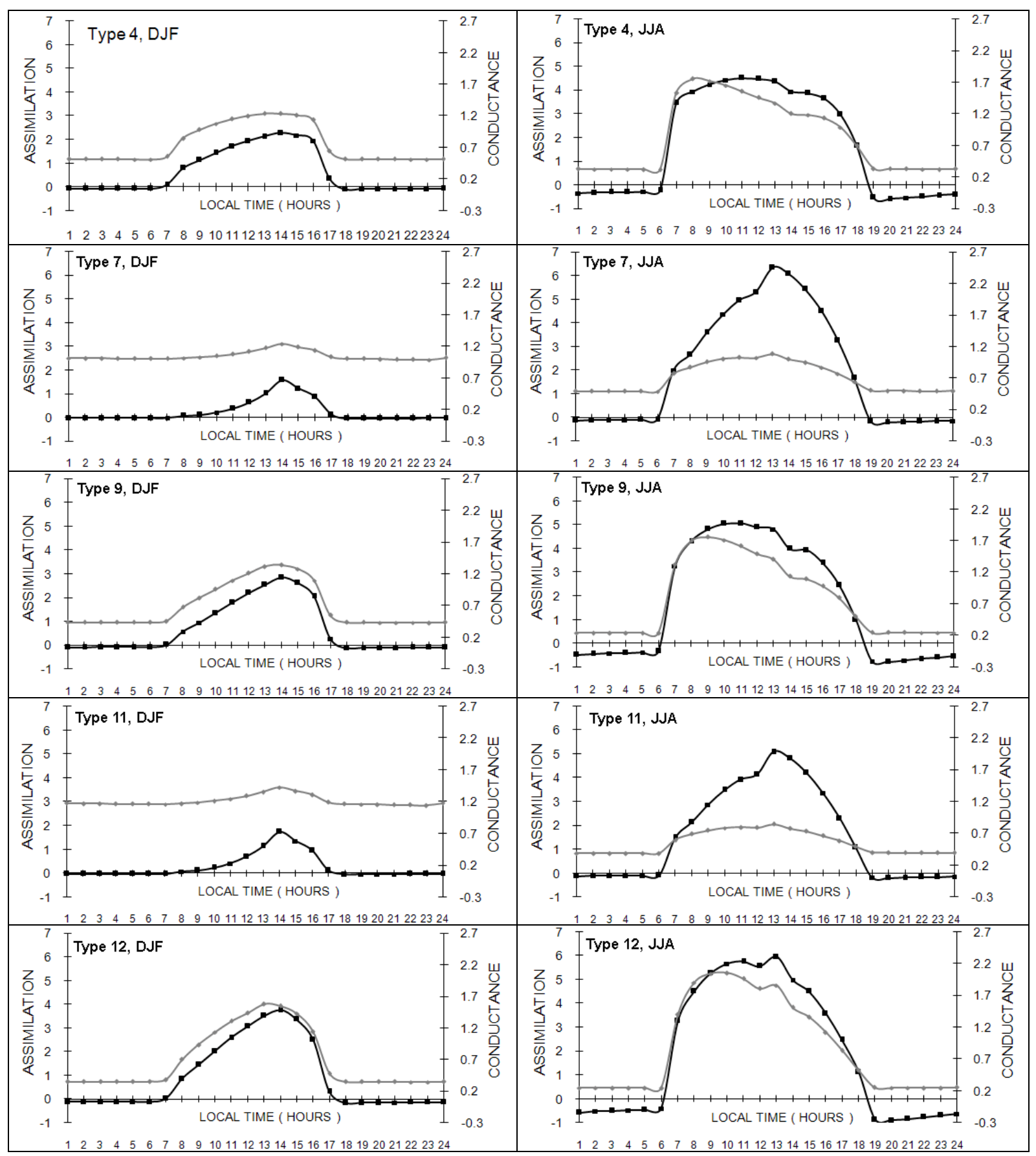

Assimilation Conductance -

FIG. 3. Canopy assimilation (tick line) $\mu$. moles. $\mathrm{m}^{-2} \cdot \mathrm{s}^{-1}$ on the left axis and conductance (thin line) $\mathrm{m}_{\mathrm{s}} \mathrm{s}^{-1}$ on the right axis at the selected grid cell for all land cover types except the urban type for which assimilation and conductance are insignificant. Left panel represents winter (DJF) and right panel summer (JJA). 


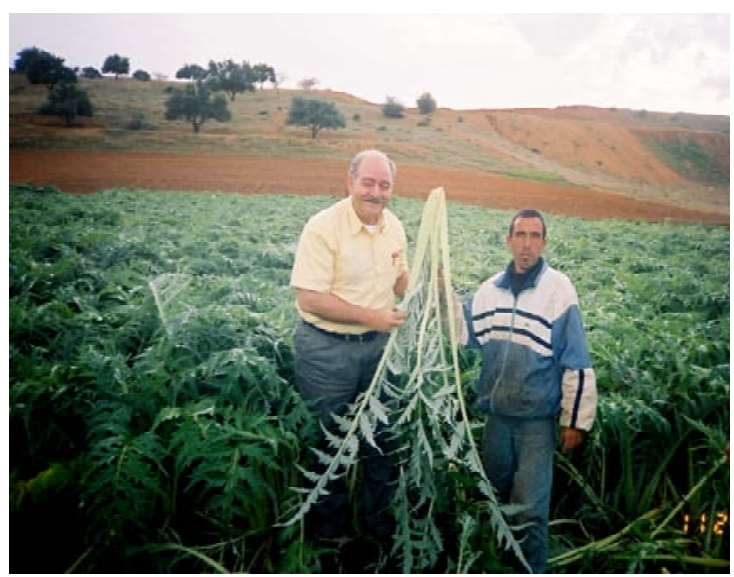

FIG. 4. Farmers in a field harvesting tall leafy cardoons (Cynara Cardunculus L.) in preparation for wheat and barley planting; November 2007. The figure also depicts some sparse tree cover, bare soils and shrubs, characteristic of the landscapes over this semi-arid region.

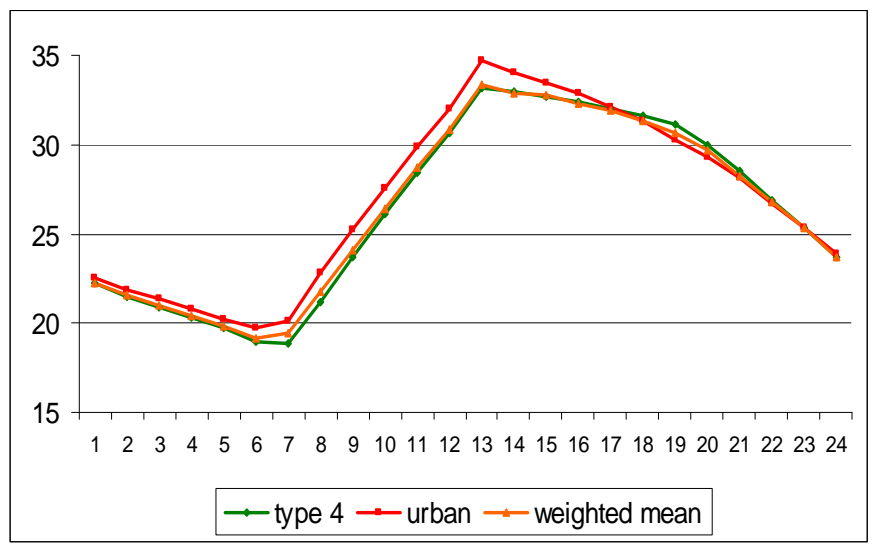

FIG. 5. Composite diurnal temperature cycles for the summer (JJA) for the selected grid cell. 


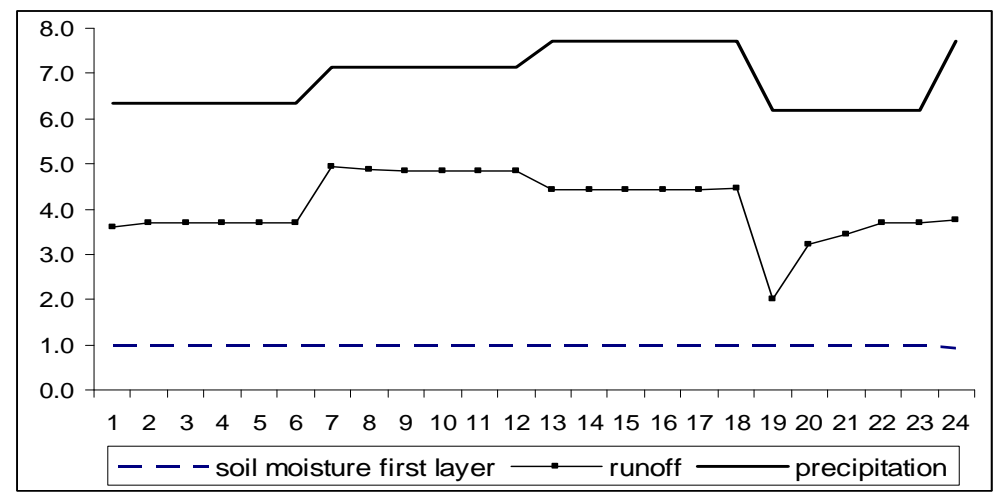

FIG. 6. Daily composite precipitation (mm.hr-1), surface runoff (mm.hr-1) and surface layer soil moisture in the urban area (\% of saturation) for the month of March. Precipitation and surface runoff are scaled by 100 for plotting purpose.

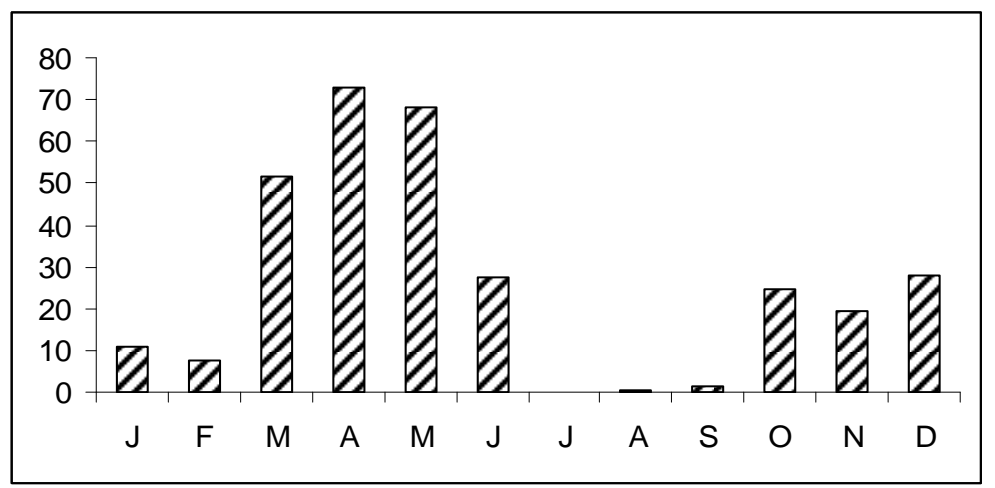

FIG. 7. Monthly mean observed precipitation ( $\mathrm{mm})$

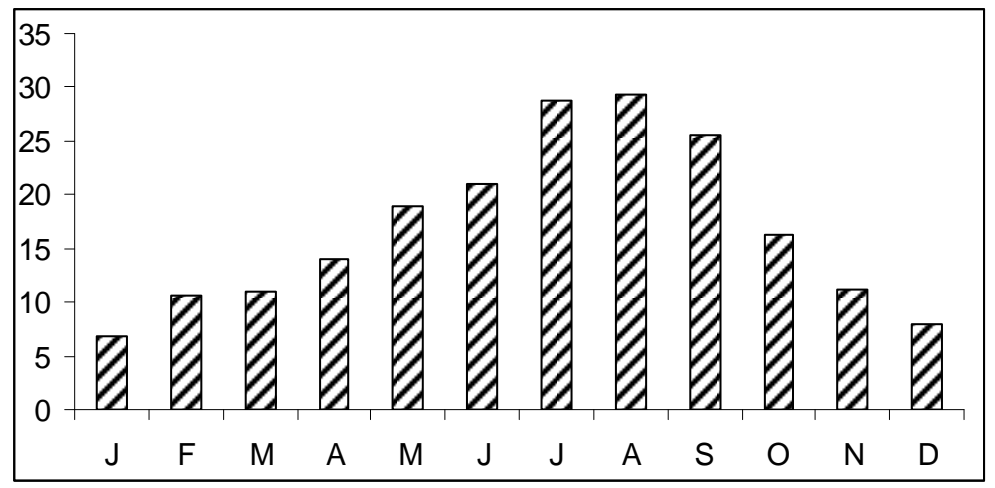

FIG. 8. Monthly mean weighted average temperature (Celsius) 


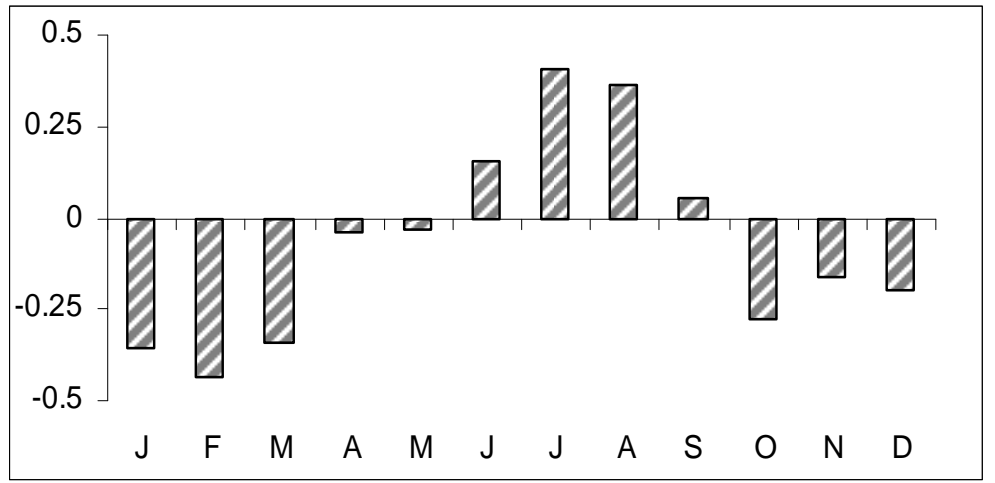

FIG. 9. Difference between the urban temperature and the Average for all other classes, averaged over the entire domain. Positive values indicate warmer temperatures for urban areas compared to surroundings.

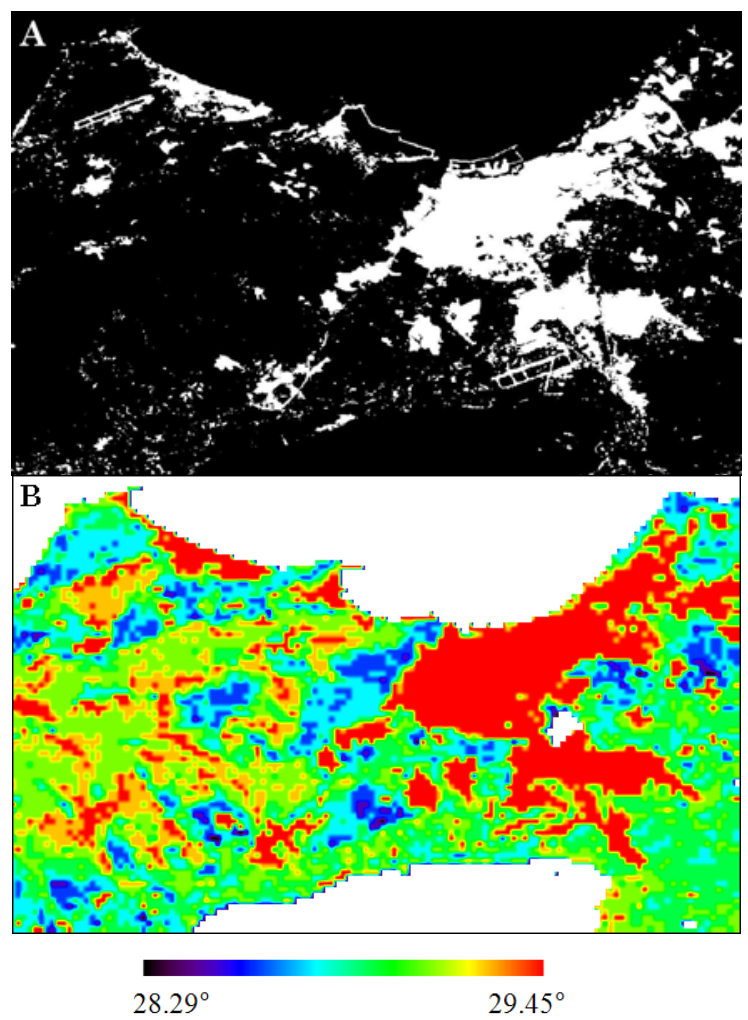

FIG. 10. A) The extent of the urban area at $25 \mathrm{~m} \times 25 \mathrm{~m}$ resolution (in white) and $\mathrm{B}$ ) the simulated monthly mean surface temperature (JJA). The simulated temperature is resampled to $25 \mathrm{mx} 25 \mathrm{~m}$ for plotting purpose. 


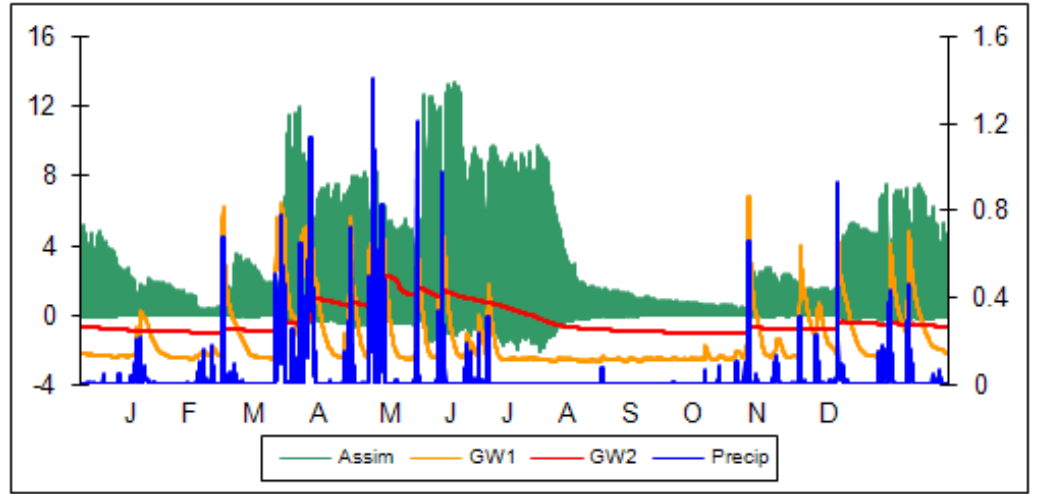

FIG. 11. Hourly evolution of simulated assimilation rate in $\mu$ moles. $\mathrm{m}^{-2} \cdot \mathrm{s}^{-1}$ (left axis), surface layer (GW1), root zone layer (GW2) soil moisture content in percent (right axis) and observed precipitation in $\mathrm{mm} \cdot \mathrm{hr}^{-1}$ (right axis).

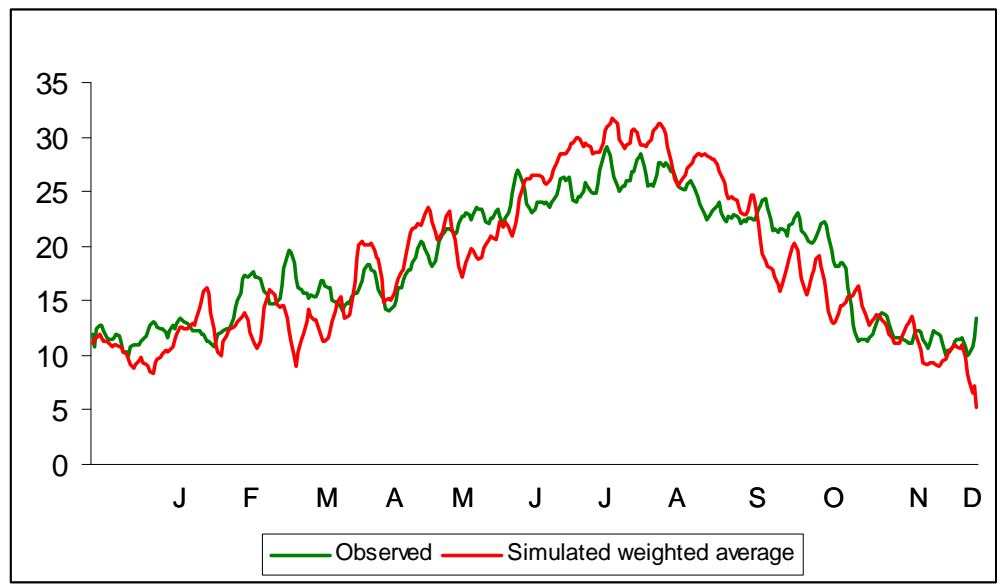

FIG. 12. Five day running-mean observed temperature at a single station in the study area and the domain averaged weighted mean simulated daily temperature (Celsius) for 2002 . 